\title{
PERAN INTELIJEN KEJAKSAAN NEGERI BANGGAI DALAM MENGUNGKAP DUGAAN TINDAK PIDANA KORUPSI
}

\author{
${ }^{1}$ Sulistia Rahman, ${ }^{2}$ H.M. Ikhwan Rays, ${ }^{3}$ Risno Mina \\ ${ }^{1,2,3}$ Fakultas Hukum Universitas Muhammadiyah Luwuk \\ ${ }^{1}$ sulistiarahman1234@gmail.com, ${ }^{2}$ Ikhwanrays63@gmail.com. \\ risnomina78@gmail.com
}

\begin{abstract}
ABSTRAK
Penelitian ini bertujuan untuk memahami peran Intelijen Kejaksaan Negeri Banggai dalam mengungkap dugaan tindak pidana korupsi. Jenis peneilitian adalah penelitian hukum empiris. Adapun peran yang dilakukan yaitu mengumpulkan data dan keterangan awal terkait adanya peristiwa pidana yang dilakukan secara melawan hukum serta terindikasi kerugian negara. Seksi Intelijen bertanggung jawab menyediakan data dan informasi untuk Pimpinan dalam pengambilan keputusan, tindakan dan perencanaan. Penyelidikan dilakukan oleh Seksi Intelijen ialah mengungkap adanya tindak pidana korupsi baik itu laporan masyarakat maupun penemuan Tim Intelijen. Teknik penyelidikan yang digunakan terdiri atas dua yakni penyelidikan terbuka dan tertutup. Faktor yang menghambat Intelijen Kejaksaan yakni keterbatasan jumlah Jaksa Penyelidik, kesulitan mendapatkan dokumen, masuknya laporan yang tidak objektif, dan keberadaan target operasi yang sering berpindah-pindah tempat. Upaya yang dilakukan yaitu penguatan jaringan terhadap pemerhati, mahasiswa, LSM, wartawan/media, masyarakat serta pengamanan personel dan materi dalam pengungkapan dugaan tindak pidana korupsi.
\end{abstract}

Kata kunci: Intelijen, Kejaksaan, Korupsi

\section{ABSTRACT}

This study aims to understand the role of the Banggai District Attorney's Intelligence in uncovering allegations of corruption. This type of research is empirical legal research. The role carried out is to collect data and initial information related to criminal events that were carried out against the law and indicated state losses. The Intelligence Section is responsible for providing data and information to the leadership in making decisions, actions and planning. The investigation carried out by the Intelligence Section is to reveal the existence of criminal acts of corruption, both public reports and the findings of the Intelligence Team. The research technique 
used consists of two, namely open and closed investigations. The factors that hinder the Prosecutor's Intelligence are the limited number of Investigating Prosecutors, difficulty in obtaining documents, the entry of reports that are not objective, and the existence of operational targets who often move from place to place. Efforts are being made to strengthen the network for observers, students, NGOs, journalists/media, the public as well as securing personnel and materials in the disclosure of alleged corruption.

Keywords: Intelligence, Prosecutor's Office, Corruption

\section{Latar Belakang}

Indonesia ialah negara hukum. Pernyataan tersebut terkandung secara eksplisit di Undang-Undang Dasar Negara 1945 Pasal 1 ayat 3. Makna dari Indonesia sebagai negara hukum yakni semua sendi kehidupan di wilayah Negara Kesatuan Republik Indonesia harus berkewajiban dan berdasar pada hukum dan produk undang-undang beserta turunannya yang diterapkan di wilayah NKRI. Indonesia menjamin adanya keadilan bagi setiap warga negaranya karena negara hukum yang ideal berprinsip pada kesamaan di hadapan hukum.

Hukum ialah aturan tertulis dan aturan tidak tertulis yang dibuat oleh lembaga negara maupun kesepakatan antara para pihak untuk membangun keteraturan dan menjaga rasa nyaman selama menjalani kehidupan di lingkungan masyarakat yang bisa berdampak bagi bangsa maupun negara. Hukum berisi aturan dan larangan. Menurut E. Utrecht dalam buku Pengantar Dalam Hukum Indonesia (1957:84) bahwa “Kumpulan regulasi yang memuat perintah maupun larangan yang menentukan ketertiban hidup di masyarakat, serta perlu ditaati oleh tiap orang, yang disebut sebagai hukum. Sebab, tindakan yang melanggar ketentuan hidup bisa menimbulkan reaksi dari lembaga pemerintahan."

Hukum pidana berperan sebagai bagian dari hukum lainnya yang meliputi norma-norma yang di dalamnya terkandung perintah maupun larangan yang telah disusun oleh lembaga negara yang memiliki kewenangan sebagai perancang undang-undang dan dapat diancam 
dengan hukuman. Hukum pidana dapat ditafsirkan sebagai reaksi dari negara terhadap pelanggar peraturan sehingga hukum pidana hendaknya dipandang sebagai ultimatum remedium atau ikhtiar paling akhir dalam memperbaiki perilaku manusia.

Hukum pidana ada dua jenis, meliputi hukum pidana materil dan formil. Hukum pidana materil ialah regulasi yang merumuskan dan menetapkan perilaku-perilaku yang bisa dikenakan sanksi pidana, regulasi yang berisi ketentuan agar dapat menjatuhkan pidana dan ketentuan mengenai sanksi pidana yang bisa diberikan. Hukum pidana formil (hukum acara pidana) ialah segala ketentuan atau garis hukum yang mengatur prosedur aparat penegak hukum mulai dari Polisi, Jaksa, serta Hakim bekerja melaksanakan kewajibannya melakukan penyelidikan, penyidikan, penuntutan, hingga menjatuhkan dan melaksanakan pidana.

Perilaku pidana paling fenomena yang terjadi di Indonesia serta menjadi perhatian publik salah satunya adalah tindak pidana korupsi. Secara harfiah kata korupsi artinya keburukan, kebohongan, kebusukan, kebejatan, tidak berakhlak, melenceng dari kebaikan, hingga kalimat maupun perkataan yang menghina atau mengandung fitnah di dalamnya (Andi Hamzah, 2006:4-6). Perilaku korupsi menjadi fenomena mengingat dampaknya sangat memengaruhi berbagai aspek, ranah serta sendi-sendi kehidupan. Korupsi di Indonesia sangat marak terjadi dari hulu hingga ke hilir sehingga dapat membawa malapetaka bagi kelangsungan kehidupan berbangsa dan bernegara yang secara nyata menimbulkan kerugian keuangan negara dan perekonomian negara secara langsung ataupun tidak langsung. Selain daripada itu korupsi dapat menyebabkan terancamnya stabilitas dan keamanan negara, melambatnya pertumbuhan ekonomi suatu negara, menurunnya investasi dan tingkat kesejahteraan umum, meningkatnya kemiskinan dan ketimpangan pendapatan, membahayakan pembangunan sosial masyarakat, menurunnya kepercayaan publik terhadap lembaga negara, melemahkan kapabilitas dan kesanggupan pemerintah untuk menyelenggarakan proyek pembangunan, kemerosotan 
akhlak dan moral serta merusak nilainilai sakral demokrasi.

Berdasarkan laporan hasil riset yang dirilis oleh Transparency International Indonesia (TII) (https://ti.or.id/indeks-persepsi-korupsi2020-korupsi-respons-covid-19-dankemunduran-demokrasi/), pada 2020 IPK (Indeks Persepsi Korupsi/Corruption Perception Index) Indonesia berada di angka 37 berskala 0-100 dan dengan ranking 102 dari 180 negara. Adapun skor 0 bemakna sangat korup dan skor 100 bermakna sangat bersih. Negara yang memiliki ranking dan skor yang sama adalah Gambia. Padahal pada tahun 2019 Indonesia masih berada di ranking 85. Jika diperbandingkan dengan negara-negara di wilayah Asia Tenggara lainnya, IPK Indonesia berada pada peringkat lima di bawah Timor Leste (40), Malaysia (51), Brunei Darussalam (60), Singapura (85).

$$
\text { Evi Hartanti (2009:2-3) }
$$

menjelaskan bahwa sektor yang sangat rentan terhadap tindak pidana korupsi yaitu kepolisian, pengadilan hingga partai politik. Masyarakat condong melakukan praktik suap menyuap pada sektor keuangan, tanah milik/bangunan, nonkonstruksi, pertahanan keamanan serta sektor minyak dan gas.

Telah banyak regulasi yang dijadikan sebagai landasan untuk memberantas korupsi sekaligus pendirian lembaga pemberantasan tindak pidana korupsi yang diharapkan dapat mengantisipasi serta mencegah terjadinya penyimpangan tersebut agar kegiatan pembangunan dan roda perekonomian bisa dijalankan sesuai koridornya sehingga perlahan-lahan akan memberikan peningkatan kualitas pembangunan dan mewujudkan kesejahteraan masyarakat luas. Walaupun demikian, pada realitanya upaya tersebut belum berhasil memberangus perbuatan korupsi secara keseluruhan. Hal ini memberi pertanda bahwa aspek kebijakan kriminal dari aparat penegak hukum yang ada belum dapat menjalankan perannya secara signifikan dalam upaya penumpasan perbuatan korupsi.

Pengungkapan kasus tindak pidana korupsi memerlukan durasi panjang karena pelaku menggunakan modus dengan metode dan pola yang kompleks dalam melancarkan aksinya. Akan tetapi dalam melaksanakan tugas yakni proses pengungkapan, Kejaksaan 
dituntut untuk melaksanakannya secara cepat dan tepat sebab waktu yang diberikan oleh undang-undang sungguh terbatas. Hal tersebut dikarenakan Kejaksaan adalah sebuah institusi yang menjalankan prosedur dalam menyelidiki maupun menyidik kasus korupsi.

Kejaksaan merupakan lembaga hukum yang eksis sejak masa kerajaan Hindu-Jawa dalam wilayah Jawa Timur, yakni zaman Kerajaan Majapahit. Sebutan "Dharmadhyaksa”, "Dhyaksa", dan "Adhyaksa" berakar kata dari bahasa lama yakni Bahasa Sanskerta yang mempunyai tafsiran jabatan atau posisi tertentu di kerajaan. Menurut Ensiklopedia Dunia versi daring

(http://www.ensiklopedia.web.id)

seorang periset asal Belanda bernama W.F. Stutterheim mengemukakan bila "Dhyaksa" merujuk pada pejabat negara Kerajaan Majapahit. Dhyaksa bertugas menangani masalah peradilan dalam persidangan di pengadilan. Setelah Indonesia merdeka maka dirancanglah peraturan tentang Kejaksaan yang telah berulang kali mengalami pergantian, peraturan terbaru yaitu Undang-Undang Nomor 16 Tahun 2004.

Dasar hukum bagi Jaksa selama melaksanakan penyidikan pada kasus korupsi tercantum dalam UndangUndang No.16 Tahun 2004 mengenai Kejaksaan yang ditetapkan pada Pasal 30 ayat 1 huruf d yang menguraikan bila Jaksa berkewenangan sebagai penyidik pada tindak pidana tertentu sesuai ketentuan yeng tercantum dalam UU. Pada penjelasan tersebut, interpretasi "berdasarkan undangudang" yakni Peraturan UU Nomor 31 Tahun 1999 mengenai Pemberantasan Tindak Pidana Korupsi sesuai yang sudah diubah dengan Peraturan UU Nomor 20 Tahun 2001 terkait Pemberantasan Tindak Pidana Korupsi. Supremasi hukum pada tindak pidana salah satunya yang harus ditempuh adalah tahap penyelidikan yang merupakan fase awal atau tahap pertama dalam rangka mencari informasi dan bahan-bahan keterangan dari sumber terpercaya dan dapat dipertanggungjawabkan keasliannya. Atas dasar tersebut terdapat dua jenis intelijen yang berperan dalam supremasi hukum di Indonesia ialah intelijen Kepolisian Republik Indonesia 
maupun intelijen yang dimiliki oleh Kejaksaan. Tidak hanya itu, terdapat pula intelijen atas kepemilikan negara yang berperan spesifik terkait pertahanan maupun keamanan yang sangat diperlukan bagi kepentingan nasional. Intelijen negara berperan sebagai penjaga keamanan dan pembela kepentingan nasional tanpa intervensi dan ancaman dari negara lain.

Selaku lembaga negara yang memperoleh wewenang dari peraturan perundang-undangan guna menyelenggarakan prosedur penyidikan pada persoalan tindak pidana tertentu. Sehingga guna membantu proses penyidikan, Kejaksaan memiliki Seksi Intelijen agar menjalankan kegiatan penyelidikan, pengamanan, dan penggalangan hingga pengukuhan kesadaran hukum masyarakat di wilayah hukumnya. Penyelidikan dari Intelijen muncul dari informasi yang didapat dari temuan jaksa maupun temuan yang didapat oleh bagian Intelijen itu sendiri (Saidil Adri, 2018:10). Hal ini diatur secara jelas dalam Peraturan Jaksa Agung Indonesia No.PER-009/A/J.A/01/2011 Pasal 622 terkait Organisasi dan Tata Kerja Kejaksaan Indonesia.
Intelijen juga dimaknai sebagai pisau analisis yang sanggup mengolah dan menyerap dinamika yang berkembang dalam masyarakat menjadi sebuah data yang disajikan secara cermat dalam bentuk informasi tuntas, jelas, lengkap dan utuh. (Persatuan Jaksa Indonesia, 2020,http://pji.kejaksaan.go.id/index.ph p/home/berita/1106, 19 Mei 2021) Agar dapat melakukan proses penyelidikan secara optimal, oleh sebab itu Seksi Intelijen Kejaksaan bertanggung jawab dalam melakukan investigasi mulai dari tahap perencanaan, aktivitas pengumpulan data, pengolahan data hingga penggunaan dan penyampaian sesuai yang tercantum dalam Peraturan Jaksa Agung Nomor PER-037/A/J.A/09/2011 terkait Standar Operasional Prosedur Intelijen Kejaksaan Republik Indonesia. Butuh keberanian seorang Jaksa untuk bisa mengungkap kasus-kasus korupsi yang terjadi di wilayah hukum Kabupaten Banggai. Mengingat perbuatan yang merugikan rakyat tersebut kerap berkaitan dengan orang penting baik dari kalangan birokrat, politisi bahkan disinyalir dari oknum aparat hukum sendiri. 


\section{Metode Penelitian}

Penelitian ini bersifat sebagai penelitian hukum empiris. Mukti Fajar \& Yulianto Achmad (2010:153) menuturkan bila penelitian hukum empiris ialah suatu riset yang memanfaatkan fakta bersifat empiris yang diperoleh dari tingkah laku manusia, salah satunya perilaku verbal yang didapatkan dari kegiatan wawancara. Selanjutnya responden dalam penelitian ini ialah pihak-pihak yang dapat merespon atau menjawab pertanyaan dalam penelitian baik secara lisan maupun tertulis.

\section{Hasil dan Pembahasan}

\section{A. Peran Intelijen Kejaksaan Negeri Banggai Dalam Pengungkapan Dugaan Tindak Pidana Korupsi}

Intelijen ialah aktivitas memata-matai/spionase yang dijalankan oleh suatu negara agar mendapatkan data rahasia tentang informasi dalam ranah militer, teknologi, ekonomi, politik, sosial maupun budaya, agar dapat memperoleh pengetahuan terkait pihak lain. Sedangkan kontra intelijen berupaya untuk mendapatkan informasi tentang agen-agen yang melaksanakan aktivitas mata-mata untuk negara lain (Soesilo Prajogo, 2007:218) adapun menurut Kunarto (1999:19) bahwa "Intelijen merupakan bahan keterangan yang telah diproses oleh personel intelijen sebagai produk atau suatu hasil akhir yang diperoleh dari kegiatan pengolahan bahan keterangan. Intelijen memuat berbagai pembahasan yang dipergunakan dalam penyusunan rencana untuk penentu kebijakan dalam pengambilan keputusan atau tindakan."

Arief Wahyudi selaku Kepala Seksi Intelijen Kejaksaan Negeri Banggai, (wawancara, 30 Juni 2021) mengemukakan bahwa Intelijen Kejaksaan berperan dalam pelaksanaan kegiatan Penyelidikan, Pengamanan, dan Penggalangan. Intelijen Kejaksaan menitikberatkan pada penegakan hukum non yustisial maupun yustisial baik preventif maupun represif. Penegakan hukum non yustisial terdiri atas bidang sosiologi, sosial, budaya, pertahanan dan keamanan. Sedangkan penegakan hukum yustisial menitikberatkan pada bidang ekonomi yaitu pengungkapan kasus tindak pidana korupsi.

Adapun definisi Penyelidikan, Pengamanan dan Penggalangan yang 
dijalankan oleh Intelijen Kejaksaan sesuai dengan yang tercantum dalam Peraturan Jaksa Agung Nomor PER037/A/J.A/09/2011 tentang Standar Operasional Prosedur Intelijen Kejaksaan Republik Indonesia (SOP) yaitu Penyelidikan Intelijen adalah segala tindakan, pekerjaan, kegiatan dan usaha yang dijalankan dengan terencana dalam siklus kegiatan intelijen guna mencari, menggali, memperoleh hingga mengumpulkan informasi yang berasal dari sumber terbuka maupun sumber tertutup. Seksi Intelijen memperoleh informasi dan bahan keterangan dari kegiatan penyelidikan terbuka dan penyelidikan tertutup.

Pengamanan Intelijen adalah serangkaian tindakan, langkah atau upaya yang dilaksanakan dengan terencana secara bertahap serta berkelanjutan guna mengamankan Negara, Pemerintah, Lembaga atau Organisasi dari segala hal-hal yang mengancam, mengganggu, menghambat dan tantangan eksternal dan internal. Hal ini sebagaimana yang dikemukakan oleh Arief Wahyudi selaku Kepala Seksi Intelijen Kejaksaan Negeri Banggai, (wawancara, 30 Juni 2021) bahwa pengamanan yang dilakukan oleh Intelijen juga dimaksudkan untuk mengamankan sumber daya manusia terhadap pekerjaan yang dilaksanakan oleh Seksi Intelijen misalnya mengamankan kegiatan penggalangan yang dilakukan langsung di masyarakat dan mengamankan data yang telah diperoleh.

Penggalangan Intelijen adalah segala tindakan, pekerjaan, kegiatan dan usaha yang dilaksanakan oleh organisasi intelijen secara berkesinambungan dalam suatu siklus kegiatan intelijen untuk memanfaatkan potensi masyarakat (perorangan, kelompok maupun masyarakat pada umumnya) dalam kurun waktu tertentu agar mendatangkan kemudahan memperoleh informasi bagi Kejaksaan sehingga Intelijen dapat mengetahui informasi/keterangan dari masyarakat yang mengetahui, mendengar dan melihat. Hal ini selaras dengan peran Intelijen yang strategis dan krusial sebagai mata dan telinga Pimpinan.

Lebih lanjut, Arief Wahyudi selaku Kepala Seksi Intelijen Kejaksaan Negeri Banggai, (wawancara, 30 Juni 2021) mengatakan 
bahwa Intelijen Kejaksaan berperan dalam kegiatan penyelidikan yakni mengumpulkan data dan keterangan awal yang dapat menunjukkan terjadinya peristiwa pidana yang dilakukan secara melawan hukum serta adanya indikasi kerugian negara walaupun belum dijabarkan secara detail. Pengumpulan data dan keterangan awal tersebut merupakan tahap permulaan untuk mengungkap kasus korupsi sehingga tahap penyelidikan dapat diartikan sebagai penentuan dapat atau tidaknya suatu peristiwa untuk dilanjutkan ke tahap penyidikan.

Dasar hukum yang digunakan oleh Intelijen Kejaksaan yaitu UndangUndang No.8 Th. 1981 tentang Hukum Acara Pidana Pasal 1 angka 5, Pasal 5 ayat 1 \& 2, serta Pasal 284, UndangUndang-Undang No.17 Th. 2011 tentang Intelijen Negara, UndangUndang Nomor 16 Th. 2004 tentang Kejaksaan Republik Indonesia, Undang-Undang No.20 Th. 2001 tentang Pemberantasan Tindak Pidana Korupsi, dan Peraturan Pemerintah Nomor 27 Th. 1983 tentang Pelaksanaan Kitab Undang-Undang Hukum Acara Pidana.
Penyelidikan tidak dapat dikatakan sebagai sesuatu yang tersendiri dan terpisah dari kegunaan penyidikan akan tetapi aktivitas penyelidikan merupakan salah satu metode ataupun cara yang menyatu dengan kegunaan penyidikan itu sendiri serta mengawali aktivitas lain berupa penangkapan, penahanan, penggeledahan, penyitaan, pemeriksaan surat, pemanggilan, tindakan pemeriksaan penyelesaian dan penyerahan berkas perkara kepada Penuntut Umum. Adapun motivasi, kepentingan dan hal yang melatar belakangi dilaksanakannya kegunaan penyelidikan yakni untuk menyediakan perlindungan dan menjunjung tinggi hak asasi manusia serta mengaitkan bahwa tidak semua peristiwa yang terjadi dan diduga sebagai tindak pidana itu menampilkan bentuknya secara jernih sebagai tindak pidana. Maka dari itu sangat penting untuk menentukan terlebih dahulu sesuai keterangan dan fakta yang termuat dalam hasil penyelidikan bahwa peristiwa yang terjadi dan diduga sebagai tindak pidana itu benar adanya dapat disebut sebagai tindak pidana sehingga dapat dilanjutkan pada tahap 
penyidikan. (Pedoman Pelaksanaan Kitab Undang-Undang Hukum Acara Pidana 1982:27)

Sedangkan tanggung jawab Seksi Intelijen menurut Arief Wahyudi selaku Kepala Seksi Intelijen Kejaksaan Negeri Banggai, (wawancara, 30 Juni 2021) yaitu menyiapkan dan menyerahkan data informasi ataupun materi informasi untuk Kepala Kejaksaan agar dapat dijadikan pertimbangan dalam mengambil suatu keputusan dimulai dari fase perencanaan, pengumpulan keterangan, pengolahan data hingga tahap penyampaian dan penggunaan.

Adapun uraian dari tahapantahapan sesuai yang tercantum dalam Peraturan Jaksa Agung Nomor PER037/A/J.A/09/2011 mengenai Standar Operasional Prosedur Intelijen Kejaksaan Republik Indonesia (SOP) adalah sebagai berikut:

1. Tahap Perencanaan

Perencanaan Penyelidikan Intelijen merupakan persiapan menjalankan kegiatan penyelidikan yang diatur secara teliti tentang aktivitas yang akan dijalankan oleh Tim Intelijen sesuai surat perintah dari Kepala Kejaksaan. Ketika telah menerima perintah dari Pimpinan Kejaksaan yang dijadikan sebagai acuan ketika sedang menjalankan tugas, selanjutnya Seksi Intelijen melaksanakan tahap perencanaan sehingga kegiatan Intelijen dapat berjalan secara sistematis dan tepat sasaran demi tercapainya hasil yang optimal.

2. Tahap Pengumpulan Data dan Bahan Keterangan

Setelah melewati tahap perencanaan terkait aktivitas yang akan dilakukan, Seksi Intelijen kemudian mengumpulkan data dan bahan keterangan. Tahap pengumpulan data dan bahan keterangan dalam mengungkap terjadinya tindak pidana korupsi memerlukan ketelitian dan ketelatenan oleh Seksi Intelijen sehingga dipandang perlu untuk memperhatikan jalannya kegiatan intelijen dan operasi intelijen.

3. Tahap Pengolahan Data

Setelah melalui tahap perencanaan dan pengumpulan data serta bahan keterangan maka tahapan selanjutnya yakni mengolah hasil informasi dan keterangan yang telah 
dikumpulkan. Informasi dan datangnya limpahan perkara yang keterangan tersebut dinilai, dicatat, berasal dari Kepolisian. Hal ini dievalusi, dan diolah agar bahan sebagaimana yang dikemukakan oleh informasi yang mentah Arief Wahyudi selaku Kepala Seksi bertransformasi menjadi suatu Intelijen Kejaksaan Negeri Banggai, produk intelijen siap pakai. (wawancara, 30 Juni 2021). Lebih 4. Tahap Penyampaian dan lanjut disampaikan bahwa penyelidikan Penggunaan yang dijalankan oleh Seksi Intelijen Tahap terakhir ialah dalam mengungkap adanya tindak penyampaian dan penggunaan. pidana korupsi berawal dari adanya Pada tahapan ini Seksi Intelijen laporan masyarakat yang masuk ke menyampaikan data atau informasi yang telah dikumpulkan dan melewati serangkaian proses penyusunan sesuai dengan mekanisme penyusunan produk intelijen yang kemudian akan dikomunikasikan kepada pengguna dalam hal ini Kepala Kejaksaan Negeri Banggai.

Tindakan yang dijalankan oleh Kejaksaan Negeri Banggai dalam melakukan penanganan terhadap tindak pidana tertentu sama halnya dengan menangani tindak pidana umum. Hanya saja pada tindak pidana tertentu, institusi Kejaksaan dalam hal ini bukan hanya berperan sebagai Penuntut Umum tetapi sekaligus berperan sebagai penyelidik dan penyidik. Sehingga tidak mesti menunggu Kejaksaan Negeri Banggai maupun penemuan dari Tim Intelijen sendiri.

Pemohon/Masyarakat mengisi buku tamu dan mengambil registrasi kemudian Petugas PPH/PPM menerima laporan dari masyarakat terkait dengan laporan mengenai tindak pidana korupsi yang menjadi kewenangan Kejaksaan Negeri Banggai yang telah diatur secara khusus dalam UU. Setelah menerima laporan atau kecurigaan yang mengarah pada indikasi-indikasi mengenai terjadinya kasus tindak pidana korupsi, maka selanjutnya laporan yang telah masuk tadi akan mendapat disposisi oleh Kepala Kejaksaan Negeri Banggai kemudian Kepala Kejaksaan mendistribusikan laporan tersebut kepada Seksi Intelijen agar segera ditindaklanjuti. 
Setelah laporan yang telah mendapat disposisi dipelajari oleh Kasi Intel, maka Seksi Intelijen membuat Telaahan Intelijen (Lahin) atas laporan yang berasal dari masyarakat tersebut. Laporan pengaduan masyarakat ditelaah dengan melakukan analisa terhadap laporan dan membuat kesimpulan sementara mengenai gambaran singkat atas keinginan pelapor dalam perspektif aturan hukum.

Telaahan Intelijen (Lahin) berisikan tentang sumber informasi, pokok permasalahan, dan saran tindak yang memberikan gambaran kepada Pimpinan mengenai langkah-langkah yang selanjutnya akan diambil. Dari situ keluarlah Surat Perintah Tugas (Sprintug) yang diterbitkan dan ditandatangani oleh Kepala Kejaksaan Negeri Banggai dan ditujukan kepada Seksi Intelijen agar dapat melakukan penguatan kegiatan Pengumpulan Bahan Keterangan (Pulbaket) dan Pengumpulan Data (Puldata) sebagai pendukung laporan tadi. Kemudian Seksi Intelijen menjalankan serangkaian tindakan dalam pembuatan Analisa Sasaran (Ansas), Analisa Tugas (Antug) dan penentuan Target Operasi (TO).
Analisa sasaran atau biasa disebut Ansas adalah analisa yang diciptakan oleh orang yang melaksanakan operasi intelijen untuk meninjau sasaran penyelidikan secara rinci dan teliti. Sedangkan Analisa Tugas atau biasa disebut Antug merupakan analisa yang diciptakan oleh pelaksana operasi intelijen agar memperoleh rincian dan analisa terkait bahan keterangan atau data yang mesti dicari dan dikumpulkan, tata cara melaksanakan Penyelidikan, Pengamanan dan Penggalangan (LIDPAMGAL). Rentan waktu dan tempat untuk menyampaikan laporan serta mekanisme yang akan dipakai dalam melakukan penggalian terhadap bahan keterangan dari sasaran maupun sumber. Selain daripada itu, Antug merupakan elemen yang berpengaruh agar proses penyelidikan dapat dijalankan secara mudah karena Antug tersebut berisi tentang pembagian tugas Tim Intelijen.

Kemudian tim dari Seksi Intelijen menentukan Target Operasi (TO) atau orang yang paling bertanggungjawab dalam kasus tindak pidana korupsi sehingga kegiatan intelijen dapat dijalankan sesuai 
perencanaan yang terarah, terukur dan matang guna memperoleh penguatan dalam kegiatan Pengumpulan Bahan Keterangan (Pulbaket) dan Pengumpulan Data (Puldata). Intelijen Kejaksaan Negeri Banggai melakukan Pulbaket dan Puldata secara tertutup dan terbuka. Secara terbuka yakni Tim Intelijen secara langsung mengadakan wawancara terhadap nama-nama yang sudah dicantumkan dalam Ansas, Antug, dan TO serta melakukan observasi terhadap benda, tempat, kejadian/situasi yang ada di lapangan dan memiliki kaitan dengan dugaan tindak pidana korupsi. Sedangkan secara tertutup yakni secara sembunyi sehingga tidak diketahui oleh orang lain diantaranya elisitasi, surveillance hingga penyamaran.

Dalam kegiatan Pengumpulan Bahan Keterangan (Pulbaket) dan Pengumpulan Data (Puldata) Seksi Intelijen menurut Arief Wahyudi selaku Kepala Seksi Intelijen Kejaksaan Negeri Banggai, (wawancara, 30 Juni 2021) menggunakan taktik dan teknik sebagai berikut:
a) Penyelidikan
Terbuka, yaitu penyelidikan yang

menggunakan cara terang-terangan meliputi kegiatan wawancara dan observasi.

b) Penyelidikan Tertutup, yaitu dengan elisitasi, Surveillance, dan penyamaran.

Setelah melakukan proses Pulbaket dan Puldata serta informasi yang dibutuhkan telah lengkap didapatkan, Tim Intelijen membuat Laporan Hasil Pelaksanaan Tugas (Laphastug) sebagai laporan kepada Pimpinan. Laphastug berisi deskripsi kegiatan intelijen yang terdiri atas hasil wawancara, hasil temuan data yang ditemukan pelaksana tugas, analisa fakta-fakta yang diperoleh di lapangan untuk dihubungkan dengan aturan hukum terkait, kesimpulan serta saran tindak kepada Pimpinan agar dapat menerbitkan Sprint Ops Intelijen (Surat Perintah Operasi Intelijen).

Atas Laporan Hasil Pelaksanaan Tugas (Laphastug) tersebut dilakukanlah Pra-Ekspos yakni penyampaian hasil pelaksanaan Surat Perintah Tugas yang dijabarkan dalam bentuk laporan atau matriks. Tahap Pra-Ekspos melibatkan para Jaksa yang berasal dari seksi lain bukan hanya Jaksa dari Seksi Intelijen untuk 
memberi pendapat, masukan dan saran mengenai Hasil Pelaksanaan Tugas. Pada kegiatan Pra-Ekspos para Jaksa tersebut dimintakan persetujuan oleh Kepala Seksi Intelijen dan Kepala Kejaksaan Negeri Banggai mengenai tindak lanjut yang akan ditempuh apakah dari Laphastug dapat ditindaklanjuti ke tahap Operasi Intelijen Yustisial.

Apabila Kepala Kejaksaan Negeri dan Peserta Pra-Ekspos telah mencapai kesepakatan atas hasil pelaksanaan tugas Tim Intelijen, kasus tersebut dimintakan persetujuan kepada Kepala Seksi Intelijen. Dengan adanya persetujuan itu maka Kepala Kejaksaan Negeri Banggai mengeluarkan Surat Perintah Operasi Intelijen (Sprint Ops Intelijen). Operasi Intelijen merupakan serangkaian tindakan, kegiatan, dan usaha yang dilakukan berdasarkan perencanaan dalam rangka menggapai suatu tujuan yang rinci dan spesifik dalam pertalian ruang dan waktu yang telah diatur dan dilaksanakan berdasarkan perintah Pimpinan Kejaksaan yang memegang kewenangan.

Kegiatan Operasi Intelijen dimaksudkan agar Jaksa Penyelidik dapat mendalami hasil pelaksanaan tugas sebelumnya. Pada tahap Operasi Intelijen terhadap tindak pidana korupsi yang sedang dilakukan penelusuran dan pendalaman, sudah timbul perbuatan melawan hukum formil maupun materil. Pada giat Operasi Intelijen Tim Ops Intelijen dapat secara resmi memberikan surat undangan panggilan kepada orang yang akan dimintai keterangan.

Hasil keterangan yang diperoleh dituangkan ke dalam Berita Acara Permintaan Keterangan kemudian Tim Ops Intelijen melakukan analisa dan pengolahan terhadap BA Permintaan keterangan tersebut. Jika selesai maka dibuat kesimpulan dan saran tindak. Apabila telah melalui tahap pengumpulan bahan dan data-data pendukung dalam Operasi Intelijen selanjutnya Tim Ops Intelijen membuat Laporan Hasil Operasi Intelijen yang berisi informasi-informasi, kesimpulan, dan saran tindak.

Ketika Intelijen menemukan adanya suatu indikasi awal yang sangat kuat serta dapat dibuktikan dengan keterangan dan data-data yang diperoleh maka diadakan Ekspos (Gelar Perkara) yakni penyampaian hasil 
pelaksanaan Surat Perintah Operasi Intelijen yang dijabarkan dalam bentuk laporan dan matriks.

Ekspos (Gelar Perkara) dihadiri oleh Kepala Kejaksaan Negeri Banggai, Kasi Intelijen, Kasi Pidana Khusus, dan para Jaksa dari seksi lain kemudian para Jaksa menentukan dapat atau tidaknya ditingkatkan ke tahap penyidikan. Jika telah mencapai kesepakatan maka akan dilaksanakan serah terima berkas penyelidikan bersama alat bukti dari Seksi Intelijen kepada Seksi Pidana Khusus untuk dilaksanakan penyidikan. Selanjutnya perkara yang dinaikkan ke tingkat penyidikan merupakan perkara tindak pidana korupsi yang menurut Jaksa Penyelidik berdasarkan data dan keterangan awal yang diperoleh sudah menunjukkan adanya indikasi peristiwa pidana yang dilakukan secara melawan hukum dan menyebabkan kerugian negara.

Berdasarkan hasil penelitian bahwa pada tahun 2016 terdapat 2 laporan masyarakat dan 1 temuan intelijen. Kemudian pada tahun 2017 terdapat 3 laporan masyarakat dan 1 temuan intelijen serta pada tahun 2018 terdapat 2 laporan masyarakat dan 1 temuan intelijen. Selanjutnya pada tahun 2019 terdapat 4 laporan masyarakat dan 1 temuan intelijen serta pada tahun 2020 terdapat 3 laporan masyarakat dan 5 temuan intelijen. Sementara itu, sepanjang tahun 2021 Seksi Intelijen Kejaksaan Negeri Banggai telah menerima sebanyak 3 laporan masyarakat dan menemukan sebanyak 4 temuan perkara tindak pidana korupsi.

Dalam kurun waktu tahun 2016 hingga 2021, jumlah laporan masyarakat yang didistribusikan ke Seksi Intelijen paling banyak pada tahun 2019 yakni berjumlah 4 laporan masyarakat. Sedangkan jumlah temuan intelijen paling banyak pada tahun 2020 yakni berjumlah 5 temuan. Total laporan masyarakat yang diterima oleh Seksi Intelijen pada tahun 2016-2021 yakni 17 laporan dan total temuan intelijen yakni berjumlah 13 temuan sehingga sejak tahun 2016 hingga sepanjang tahun 2021 Seksi Intelijen Kejaksaan Negeri Banggai telah menangani sebanyak 30 perkara.

Dari hasil penelitian tersebut menunjukkan bahwa Seksi Intelijen Kejaksaan Negeri Banggai telah meningkatkan peran dan kinerjanya 
secara signifikan dalam menangani perkara tindak pidana korupsi yang terjadi di wilayah hukumnya. Hal ini dapat ditinjau terutama pada jumlah temuan intelijen yang mengalami peningkatan yang pada tahun 2020 dan sepanjang tahun 2021. Mengingat pada tahun-tahun sebelumnya Seksi Intelijen hanya mendapatkan 1 temuan pada setiap tahunnya sedangkan pada tahun berikutnya mendapatkan sebanyak 5 temuan perkara tindak pidana korupsi di Kabupaten Banggai. Sehingga dapat dimaknai Seksi Intelijen Kejari Banggai telah menjalankan peran dan peforma kinerjanya dengan sangat baik.

\section{B. Faktor Yang Menghambat Peran Intelijen Kejaksaan Negeri Banggai Dalam Pengungkapan Dugaan Tindak Pidana Korupsi}

Tindak pidana korupsi merupakan tindak pidana yang digolongkan sebagai extraordinary crime atau kejahatan luar biasa sebab pelaku menggunakan modus dengan metode dan pola yang kompleks dalam melancarkan aksinya. Pelaku korupsi cenderung berupaya membalikkan kebenaran demi memengaruhi penegak hukum. Maka dari itu dalam menjalankan tugasnya, Intelijen Kejaksaan mengalami berbagai hambatan. Menurut Arief Wahyudi selaku Kepala Seksi Intelijen Kejaksaan Negeri Banggai, (wawancara, 30 Juni 2021) beberpa hambatan sebagai berikut:

1. Seksi Intelijen Kejaksaan Negeri Banggai hanya memiliki satu orang Jaksa Penyelidik yaitu Kasi Intelijen seorang diri. Jumlah yang sungguh tidak sebanding dengan penanganan perkara. Apalagi tempat yang harus dituju sangat luas meliputi 23 Kecamatan dan 294 Desa serta ratusan pekerjaan yang tersebar dimana-mana. Hal ini menunjukkan faktor SDM (sumber daya manusia) merupakan salah satu hambatan dalam mengungkap dugaan tindak pidana korupsi. Sehingga dalam membentuk Tim, Seksi Intelijen harus melibatkan para Jaksa dari seksi lain akibatkekurangan personel.

2. Terbatasanya anggaran yang diperoleh Seksi Intelijen dalam mendukung kegiatan Intelijen terkhususnya ketika melakukan observasi di lapangan guna 
mengungkap suatu dugaan tindak pidana korupsi.

3. Sulit bagi Petugas Intelijen untuk mendapatkan dokumendokumen penting yang terkait dengan suatu kasus.

4. Tidak adanya jaminan hasil Operasi Intelijen Yustisial yang diserahkan kepada Seksi Pidana Khusus dijadikan produk perkara korupsi yang dilimpahkan ke Pengadilan TP Korupsi karena tugas Seksi Intelijen hanya sebatas melimpahkan Laporan Hasil Operasi Inteljen ke Seksi Pidana Khusus.

5. Adanya peta konflik politik di Kabupaten Banggai yang saling bertolak belakang sehingga menyebabkan masuknya laporan yang tidak didasari oleh bukti yang objektif dan terkesan subjektif serta dilandasi oleh prasangka-prasangka buruk.

6. Keberadaan Target Operasi (TO) sering berpindah-pindah tempat sehingga Tim Intelijen mengalami kesulitan untuk menemukan Target Operasi disebabkan Target Operasi tidak dapat ditemui di alamat yang tercantum secara resmi dalam data kependudukan.

C. Upaya Untuk Meningkatkan Peran Intelijen Kejaksaan Negeri Banggai Dalam Pengungkapan Dugaan Tindak Pidana Korupsi

Mengingat adanya berbagai faktor yang menjadi penghambat bagi Tim Intelijen ketika menjalankan tugasnya, maka diperlukan upaya untuk meningkatkan peran Seksi Intelijen agar dapat mengungkap dugaan tindak pidana korupsi secara efektif karena pengungkapan dugaan tindak pidana korupsi tidak dapat dijalankan sendiri sehingga harus melibatkan partisipasi pihak-pihak lain.

Adapun menurut Arief Wahyudi selaku Kepala Seksi Intelijen Kejaksaan Negeri Banggai, (wawancara, 30 Juni 2021), upaya yang dijalankan yakni melakukan penguatan jaringan terhadap pemerhati, mahasiswa, LSM (lembaga swadaya masyarakat), wartawan/media, hingga menjangkau semua lapisan masyarakat agar penguatan jaringan menjadi lebih mudah. Penguatan jaringan dimaksudkan agar orang-orang tersebut dapat dimintai secuil-secuil informasi 
sehingga informasi yang diperoleh dapat bermanfaat untuk menyukseskan tugas-tugas Tim Intelijen walaupun hanya memiliki personel dengan jumlah yang sangat terbatas.

Penguatan jaringan yang dapat dilakukan salah satunya dengan mengadakan komunikasi personal di tempat-tempat nongkrong atau melakukan penggalangan di lingkungan perumahan dengan bersandiwara agar bisa mengelabui guna menanyakan kenal atau tidaknya mereka terhadap seseorang atau pengetahuan mereka mengenai informasi penting tentang sasaran yang mereka ketahui. Upaya ini juga dapat dijalankan oleh informan yang menjalin kerjasama dengan Seksi Intelijen.

Selain itu, sangat penting bagi Intelijen untuk senantiasa mengoptimalkan kegiatan pengamanan baik pengamanan personel maupun pengamanan materi. Pengamanan personel memfokuskan pada dua aspek yaitu aspek fisik dan aspek mental. Pengamanan fisik diperlukan agar personel dapat melakukan pencegahan dan perlindungan diri dari tindakan yang membahayakan personel. Sedangkan pengamanan mental diperlukan agar personel mempunyai ketangguhan mental dan tidak mudah dipengaruhi oleh siapa pun sehingga mampu manjaga integritasnya sebagai mata dan telinga bagi Pimpinan Kejaksaan.

\begin{tabular}{rrr}
\multicolumn{2}{c}{ Pengamanan materi juga } \\
diperlukan sebagai usaha guna
\end{tabular} meningkatkan fungsi Intelijen Kejaksaan selama mengungkap dugaan tindak pidana korupsi agar mampu merintangi upaya pihak lain yang tidak bertanggungjawab yang ingin mencuri, merusak, dan memperoleh data-data Seksi Intelijen yang bersifat rahasia sebagai pencegahan terhadap penghapusan atau penyalahgunaan oleh pihak lain sehingga dipandang penting untuk dilakukan pengawasan intensif.

\section{Kesimpulan}

Peran Intelijen Kejaksaan

Negeri Banggai selama mengungkap dugaan tindak pidana korupsi yakni mengumpulkan data dan keterangan awal yang dapat menunjukkan terjadinya suatu peristiwa pidana yang dilakukan secara melawan hukum serta adanya indikasi kerugian Negara walaupun belum dijabarkan secara detail. Bertanggung jawab menyediakan, memberikan dan 
menyediakan data informasi atau materi informasi untuk Pimpinan agar dapat dijadikan dasar dalam pengambilan keputusan, tindakan, dan perencanaan. Membuat Telaahan Intelijen (Lahin) yang berisi sumber informasi. Menjalankan taktik dan teknik penyelidikan terbuka dan tertutup. Adapun beberapa faktor yang menghambat peran Intelijen Kejaksaan Negeri Banggai dalam pengungkapan dugaan tindak pidana korupsi yaitu keterbatasan jumlah Jaksa Penyelidik, keterbatasan anggaran dan kesulitan mendapatkan dokumen yang dibutuhkan. Tidak adanya jaminan hasil Operasi Intelijen Yustisial yang diserahkan kepada Seksi Pidana Khusus dijadikan produk perkara korupsi yang dilimpahkan ke Pengadilan, masuknya laporan yang tidak objektif, dan keberadaan target operasi yang sering berpindah-pindah tempat. Sedangkan upaya yang dilakukan adalah penguatan jaringan terhadap pemerhati, mahasiswa, LSM wartawan/media hingga berbagai lapisan masyarakat hingga menjamin pengamanan personel dan materi merupakan upaya yang dilakukan
Kejaksaan Negeri Banggai untuk meningkatkan peran intelijen selama mengungkap dugaan tindak pidana korupsi.

\section{Daftar Pustaka}

Andi Hamzah, 2006, Pemberantasan Korupsi Melalui Hukum Nasional dan Internasional, Raja Grafindo Persada, Jakarta.

Departemen Kehakiman Republik Indonesia, 1982, Pedoman Pelaksanaan Kitab UndangUndang Hukum Acara Pidana, Departemen Kehakiman Republik Indonesia, Jakarta

E. Utrecht, 1957, Pengantar Dalam Hukum Indonesia, Ichtiar, Jakarta.

Evi Hartanti, 2009, Korupsi (Konsep, Tindak Pidana, dan Pemberantasannya), Raja Grafindo Persada, Jakarta.

Kunarto, 1999, Intelijen Pengertian dan Pemahamannya, Cipta Manunggal, Jakarta

Mukti Fajar \& Yulianto Achmad, 2010, Dualisme Penelitian Hukum Normatif dan Empiris, Pustaka Pelajar, Yogyakarta

Saidil Adri, 2018, Peranan Intelijen Kejaksaan Tinggi Riau dalam 
Pengungkapan Dugaan Tindak

Pidana Korupsi, JOM Fakultas

Hukum Universitas Riau

Volume V Nomor 1 April 2018

Soesilo Prajogo, 2007, Kamus Hukum

Internasional dan Indonesia,

Wacana Intelektual, Jakarta

Peraturan Perundang-Undangan:

Undang-Undang Nomor 8 Tahun 1981

tentang Hukum Acara Pidana.

Undang-Undang Nomor 16 Tahun

2004 tentang Kejaksaan

Republik Indonesia.

Undang-Undang Nomor 31 Tahun

1999 tentang Pemberantasan

Tindak Pidana Korupsi.

Undang-Undang Nomor 20 Tahun

2001 tentang Perubahan Atas

Undang-Undang Nomor 31

Tahun 1999 tentang

Pemberantasan Tindak Pidana

Korupsi

Undang-Undang Nomor 17 Tahun

2011 tentang Intelijen Negara.

Peraturan Jaksa Agung Republik

Indonesia Nomor Per006/A/JA/03/2014 tentang

Perubahan Atas Peraturan Jaksa

Agung Republik Indonesia

Nomor Per-009/A/JA/01/2011

tentang Organisasi Dan Tata
Kerja Kejaksaan Republik

Indonesia.

Peraturan Jaksa Agung Republik

Indonesia Nomor Per-

037/A/JA/09/2011 tanggal 23

September 2011 tentang

Standar Operasional Prosedur

(SOP) Intelijen Kejaksaan

Republik Indonesia.

Keputusan Jaksa Agung Republik

Indonesia Nomor Kep552/A/JA/10/2002 tentang

Administrasi Intelijen Yustisial

Kejaksaan.

Sumber Lain (Internet):

Transparancy International Indonesia,

"Indeks Persepsi Korupsi 2020,

Respons COVID 19, \&

Kemunduran Demokasi”

melalui https://ti.or.id/indeks-

persepsi-korupsi-2020-korupsi-

respons-covid-19-dan-

kemunduran-demokrasi/,

diakses tanggal 29 Maret 2021.

Persatuan Jaksa Indonesia, “Jaksa Agung Burhanuddin:

Peningkatan SDM Kunci Utama

Keberhasilan Intelijen" melalui http://pji.kejaksaan.go.id/index. ph p/home/berita/1106, diakses tanggal 19 Mei 2021. 
Dunia, "JAKSA", melalui http://www.ensiklopedia.web.id/ id3/21011998/kejaksaan\%20ind onesia_100_2_0_ensiklopedia.h tml, diakses tanggal 1 Agustus 2021. 